Western University

Scholarship@Western

Department of Economics Research Reports

Economics Working Papers Archive

1994

\title{
Settlement of Litigation Under Rule 68: An Economic Analysis
}

Tai-Yeong Chung

Follow this and additional works at: https://ir.lib.uwo.ca/economicsresrpt

Part of the Economics Commons

Citation of this paper:

Chung, Tai-Yeong. "Settlement of Litigation Under Rule 68: An Economic Analysis." Department of Economics Research Reports, 9422. London, ON: Department of Economics, University of Western Ontario (1994). 


\author{
RESEARCH REPORT 9422 \\ Settlement of Litigation \\ Under Rule 68: \\ An Economic Anelysis \\ by \\ Ta1-Yeong Chung
}

November 1994

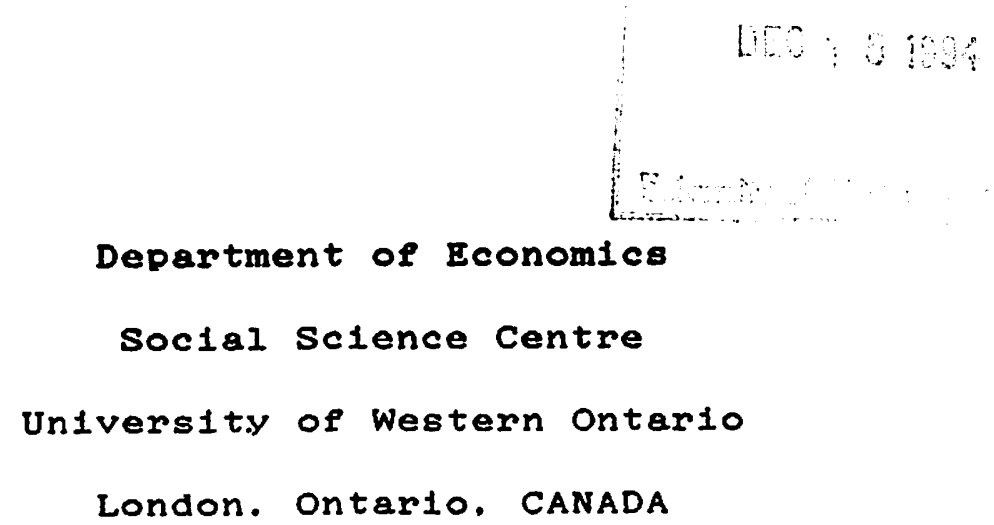

N6A $5 \mathrm{C2}$ 


\title{
Settlement of Litigation under Rule 68: \\ An Economic Analysis
}

\author{
by \\ Tai-Yeong Chung * \\ July 1994 \\ Revised, November 28, 1994
}

* Department of Economics, Social Science Centre, University of Western Ontario, London, Ontario N6A 5C2, Canada. I thank David A. Anderson, Frank Buckley, John Palmer, and seminar participants at the Sixth John M. Olin Annual Conference in Law and Economics, University of Toronto for useful comments on the previous version. I gratefully acknowledge financial support from the Social Sciences and Humanities Research Council of Canada (Grant \#410-93-0072). 


\title{
SETTLEMENT OF LITIGATION UNDER RULE 68: \\ AN ECONOMIC ANALYSIS
}

\author{
TAI-YEONG CHUNG*
}

The making of an offer of settlement is an important step in any litigation. Both to the offeror and offeree, there may flow important consequences concerning the costs of proceedings. Rule 68 of the U.S. Federal Rules of Civil Procedure provides that a plaintiff who refuses a defendant's formal settlement offer and then obtains a judgment not more favorable than the offer must pay the defendant's post-offer costs. ${ }^{1}$ Rule 68 has received increased attention in recent years as a device for encouraging settlements at a time when the courts are overflowing with litigation. Despite its purpose, it is a seldom-used litigation tool that is overlooked by many practitioners. ${ }^{2}$

A few scholars have provided economic analyses to study its effects on settlement and litigation. Most of these works argue that, contrary to its intended effect, Rule 68 reduces settlement ranges and increases litigation possibilities. ${ }^{3}$ In the standard model of litigation that has been developed over the past twenty years, a settlement range is defined as the set of settlement offers that both plaintiff and defendant would prefer to going to trial. ${ }^{4}$ The settlement range would exist if the plaintiff's minimum offer is smaller than the defendant's maximum offer. Because the existence of a settlement range is a necessary condition for settlement, the concept has been extensively used to identify the possibility of settlement under alternative rules of allocating fees and costs.

Although the standard definition of settlement range has been useful in investigating the effects of other rules of allocating fees and costs, it is argued in this article that it is inadequate in analyzing the effects of Rule 68 because the rule 
influences parties' incentives to make and accept settlement offers in quite a different way. In particular, parties' threat values before any settlement offer is made are different from their threat values after a settlement offer is made and rejected under Rule 68. The standard definition does not tell us which threat values should be used in identifying a proper settlement range, which has generated some confusion in the literature. Neither pre-offer settlement range alone (using threat values before any offer) nor post-offer settlement range alone (using threat values at each rejected offer) is enough to correctly identify the possibility of settlement under Rule 68 .

The objective of this article is to advance our understanding of the effects of Rule 68 by investigating parties' incentive to make and accept an offer in identifying settlement possibilities under the rule. An economic analysis is provided (i) to show that the conventional settlement range is inadequate in analyzing the effects of Rule 68, (ii) to present a new definition of the settlement range that is adequate for analyzing the effects of Rule 68 , and (iii) to propose a revision of Rule 68 to encourage settlements of litigation, and examine its implications.

A typical argument made in the existing literature on the settlement range under Rule 68 is as follows. The rule makes litigation more costly to the plaintiff, since even if he wins he may have to pay both parties' costs and therefore he will demand less in settlement of the case. By the same token, the defendant, who now has less to lose from litigation, will offer less. So the settlement range will not be larger. ${ }^{5}$

Although this argument is intuitive, it turns out that it is not easy to formally demonstrate the argument by using the standard definition of settlement range. According to the standard definition, an offer will be in the settlement range provided that both parties prefer it to going to trial. The standard definition of settlement range may not be directly applicable to the analysis of Rule 68 because, under the rule, parties can decide to go to trial both before an offer is made and after an offer is made. 
In Section I, a definition of settlement range which is adequate for analyzing Rule 68 and consistent with the standard one is presented (it is called the conventional settlement range). It is shown that the conventional settlement range generally expands as a result of Rule 68. The upper limit of the settlement range does not change, while its lower limit is reduced.

This argument can be illustrated in a numerical example. ${ }^{6}$ Assume that the plaintiff's expected gain from trial in the absence of Rule 68 offers is $\$ 69,600$, and that defendant's expected loss from trial is $\$ 103,600$. Assume that if the plaintiff rejects the defendant's offer of $\$ 102,000$, then defendant's expected loss from the trial becomes $\$ 101,280$ because of the potential cost-shifting effect of Rule 68 . The issue is whether the offer of $\$ 102,000$ can be in the settlement range. The defendant would prefer the settlement expense of $\$ 102,000$ to the expected loss of $\$ 103,600$ that he would incur at trial (when he does not make any offer). The plaintiff definitely prefers the settlement of $\$ 102,000$ to going to trial with the expected gain of $\$ 69,600$. If one focuses on the parties' positions before any offer is made, the offer would be in the settlement range because both parties prefer it to going to trial.

It may be argued, however, that with the settlement offer of $\$ 102,000$ the defendant would rather go to trial (with the reduced expected loss of $\$ 101,280$ ) than settle, and thus, the offer cannot be in the settlement range. It is true that once the offer has been made, the defendant would be better off if the offer is rejected than if the offer is accepted. However, it is the plaintiff (not the defendant) who can decide whether to accept or reject the offer. In fact, the plaintiff would prefer accepting the offer to going to trial since $\$ 102,000$ is considerably greater than the expected gain of only $\$ 69,600$. When such an offer is bound to be accepted, the potential cost-shifting role of Rule 68 will be irrelevant. Therefore, the above argument that the offer cannot be in the settlement range is not well-grounded. 
In examining whether an offer is in the settlement range, the definition of a conventional settlement range requires only a comparison between an offer and the parties' positions at trial. It does not require a comparison among different offers. There may be cases in which an offeror does not have an incentive to make a certain offer because he is better off by making a different offer although both offers are in the conventional settlement range. Therefore, there is a possibility that the conventional settlement range may fail to identify true settlement possibilities under Rule 68.

It is shown that some offers in the settlement range may be dominated by other offers for an offeror. Consider an offer $S_{l}$ to which acceptance is the plaintiff's best response. With the offer, defendant's expected loss in equilibrium is $S_{l}$. Consider another offer $S_{2}$ that is less than $S_{1}$. If the maximum expected loss to the defendant with the offer $S_{2}$ is less than $S_{1}$ (regardless of possibility of further negotiation after the offer is rejected), then it can be said that $S_{1}$ is dominated by $S_{2}$ for the defendant. In that case, the defendant does not have an incentive to make the dominated offer $S_{l}$. Section II provides a definition of the refined settlement range that is obtained by eliminating all dominated offers from the conventional settlement range. It is shown that the refined settlement range under Rule 68 is always (weakly) smaller than the settlement range without the rule. This result confirms the intuitive argument made in the existing literature that Rule 68 does not increase settlement range, and that its most significant effect is to redistribute wealth from plaintiff to defendant. ${ }^{7}$

To illustrate the dominance argument, consider the previous numerical example. Recall that the settlement offer of $\$ 102,000$ is shown to be in the (conventional) settlement range. Consider an offer of $\$ 101,400$. Assume that if this new offer is made and rejected, then the post-offer settlement range would be $[\$ 67,296, \$ 101,296]$. The maximum loss to the defendant with the new offer is $\$ 101,400$ which can be realized when the offer is accepted. If the offer were rejected, 
$\$ 101,296$ would be the maximum possible expected loss to the defendant regardless of the outcome of the post-offer negotiation. Since the previous offer of $\$ 102,000$ is dominated by the new offer, it cannot be in the refined settlement range.

In Section III, a policy proposal is made on the basis of this analysis. If Rule 68 is revised in a way that the plaintiff (when losing against the defendant's offer) pays the defendant's post-offer costs to a third party, not to the defendant, then the settlement range (both conventional and refined versions) will expand. Under the proposal, the aggressive plaintiff is taxed, but the amount is given not to the defendant, but to the neutral third party. This scheme maintains the original effect of the rule in punishing aggressive plaintiffs, but it also cures its perverse effects on the defendant's incentive to make offers. It is shown that, under this proposal, the settlement range (both conventional and refined) never shrinks, and in most situations, it expands.

The reason settlement can be possible as a result of this proposed Rule 68 is as follows. Suppose that settlement is not possible in the absence of Rule 68 because an optimistic plaintiffs expected gain from trial exceeds a defendant's expected loss from trial. If the cost-shifting effect of the rule imposes enough risks on the plaintiff so that the expected gain from trial (after rejecting an offer of settlement under the rule) becomes smaller than the defendant's expected loss from trial (without the rule), then settlement becomes possible under the rule.

This does not mean that settlement is always possible even under the proposed version of Rule 68. Recall that the risks created by Rule 68 must be large enough to outweigh the original gap between parties' expected gain and loss that exists in the absence of the rule. If taxable costs are too small, then the rule may not be able to create enough risks. Under a certain situation, a large offer is needed to create enough risks. In that case, it may not be advantageous for the defendant to make such an offer 
which, if accepted, could make the defendant worse off (the defendant will be better off by not making any offer).

It will be useful to identify conditions under which Rule 68 is operative because the rule has been mostly ignored in actual litigation settlements. ${ }^{8}$ Sufficient conditions under which Rule 68 expands the settlement range are identified in the subsection III-B. In particular, it is shown that Rule 68 is inoperative for all cases in which litigation outcome is dichotomous (either some fixed $J$ or nothing)..$^{9}$ Take, for example, a suit in tort under negligence rule. When the actual loss to the victim is certain and easily verifiable, the only uncertainty is whether the defendant is liable or not. It is shown that in such a case, Rule 68 does not have any effects on the parties' incentive to settle. This may explain why the rule has had limited use in practice. Rule 68 is more likely to have an impact when liability is clear, but the extent of loss to a victim is quite uncertain. Take, for example, a suit for breach of contract in which judgment at trial may take one of several possible values because of the court's error or the difficulty of measurement in assessing damages.

One potential problem of Rule 68 has been its effect on the plaintiff's incentive to bring suit. It has been argued that a meritorious plaintiff who would bring suit may not have an incentive to bring suit as a result of Rule 68 because he is facing the risks of paying both parties' costs. It is shown in the subsection III-C that the plaintiff's incentive to bring a suit is not affected with Rule 68 (whether it is the current version or the revised version). ${ }^{10}$

This article is organized as follows. In Section I, a model of litigation and settlement is presented, and the conventional settlement range under Rule 68 is defined and identified. In Section II, a refined settlement range is introduced and analyzed. In Section III, a revision of Rule 68 is proposed to enhance its effects on settlement of litigation, and its implications are discussed. In Section IV, concluding remarks are made. 


\section{RULE 68 AND THE CONVENTIONAL SETtLEMENT RANGE}

\section{$A$. when parties have the same beliefs on litigation outcomes}

The model presented here closely follows that of Miller. ${ }^{11}$ It is assumed that both plaintiff and defendant are risk neutral, that both know the (fixed) size of the other's expected costs and attorney's fees. ${ }^{12}$ It is also assumed that both have the same assessment as to the probability distribution of litigation outcomes. The latter assumption will be relaxed later. To identify the effects of Rule 68 , it is useful to look at the litigation picture in the absence of the rule and then change the model to account for the incentive effects of the rule.

\section{Settlement Incentives without Rule 68}

The way that the court allocates costs and fees has a significant effect on parties' incentives to settle under Rule 68. It is important, thus, to specify carefully what the default allocation rule is. Following Miller, consider a modified version of the American rule in which (i) each party pays his own attorney's fees regardless of the outcome of the litigation, and (ii) the losing party is assessed the costs of the litigation other than the fees - transcript costs, witness fees, printing costs, docket fees, and the like. The second feature of the default rule is based upon the Federal Rule 54(d). ${ }^{13}$

Let $x$ (non-negative) denote the size of judgment for the plaintiff to be determined in litigation. Both parties have the same assessment as to the probability distribution $G(\cdot)$ of litigation outcomes. Put another way, $G(\hat{x})$ denotes the probability that the judgment will be less than or equal to $\hat{x}$. Thus, $G(0)$ denotes the probability that defendant will win the case. Assume, without loss of generality, that there exists a maximum possible judgment $K$. Then, we obtain that (i) $0 \leq G(x) \leq 1$, for all $x$ in the 
support $[0, K]$, (ii) $G(x)=1$ for all $x \geq K$, and (iii) $G(x)$ is (weakly) increasing in $x$. Let $\bar{x}$ denote the expected value of the judgment, that is, $\bar{x}=\int_{x} d G(x)$. Let $F^{p}$ denote the plaintiff's expected attorney's fees, and $C^{p}$ denote the plaintiff's expected costs. ${ }^{14} F^{d}$ and $C^{d}$ are similarly defined for the defendant. All fees and costs are assumed to be positive.

The plaintiff's expected gain from trial can be expressed as

$$
U^{p} \equiv \bar{x}-F^{p}-G(0)\left(C^{p}+C^{\Phi}\right)
$$

This expression says that plaintiff's expected gain from trial will be the judgment expected minus defendant's expected attorney's fees, and minus the expected costs of both parties multiplied by the probability that the plaintiff will lose the lawsuit. ${ }^{15}$ It is assumed that in the absence of Rule 68 the plaintiff has an incentive to bring suit, that is, $U^{P}$ is positive. The effect of Rule 68 on the incentive to bring suit is studied in Section III.

The defendant's expected loss from trial can be similarly expressed as

$$
U^{d} \equiv \bar{x}+F^{d}+(1-G(0))\left(C^{p}+C^{d}\right)
$$

This expression says that defendant's expected loss from trial will be the sum of the expected judgment, defendant's expected attorney's fees, and the expected costs of both parties multiplied by the probability that the defendant will lose the lawsuit.

Miller distinguishes the litigation differential from the settlement range. Litigation differential means the difference between the defendant's loss from trial and the plaintiff's gain from trial. ${ }^{16}$ From (1) and (2), the litigation differential is

$$
L D \equiv U^{d}-U^{p}=F^{p}+F^{d}+C^{p}+C^{d}
$$


The litigation differential is the sum of both parties' fees and costs. When both parties have the same belief on litigation outcome, the litigation differential will be equal to the total expenses of proceeding to trial.

In the standard model of litigation, settlement range is defined as the set of settlement offers that both plaintiff and defendant would prefer to going to trial. ${ }^{17}$ Because the existence of a settlement range is a necessary condition for settlement, the concept has been extensively used to identify the possibility of settlement under alternative rules of allocating fees and costs.

The plaintiff would prefer any settlement offer greater than or equal to $U^{p}$ to going to trial. Similarly, the defendant would prefer any settlement offer less than or equal to $U^{d}$ to going to trial. Therefore, the settlement range, if it exists, consists of offers that are greater than or equal to $U^{p}$ and less than or equal to $U^{d}$. In summary, when both parties have the same belief on litigation outcomes, the settlement range without Rule 68 is $\left[U^{p}, U^{d}\right] .{ }^{18}$ Therefore, the size of the settlement range is identical to the litigation differential. Some authors define settlement range as a set of offers that are greater than or equal to the plaintiff's gain from trial and less than or equal to the defendant's loss from trial. ${ }^{19}$ As shown above, this version is consistent with the above definition used in the standard model of litigation.

\section{[Figure 1]}

These relations are illustrated in Figure $1 .{ }^{20}$ The defendant's expected loss and the plaintiff's expected gain are shown along the vertical axis. The defendant prefers smaller losses, while the plaintiff prefers larger gains. The size of the defendant's offer $S$ is shown along the horizontal axis. The relation between defendant's settlement offer and its expected loss from continuing to trial is given by the horizontal line at $U^{d}$. 
Gain/Loss

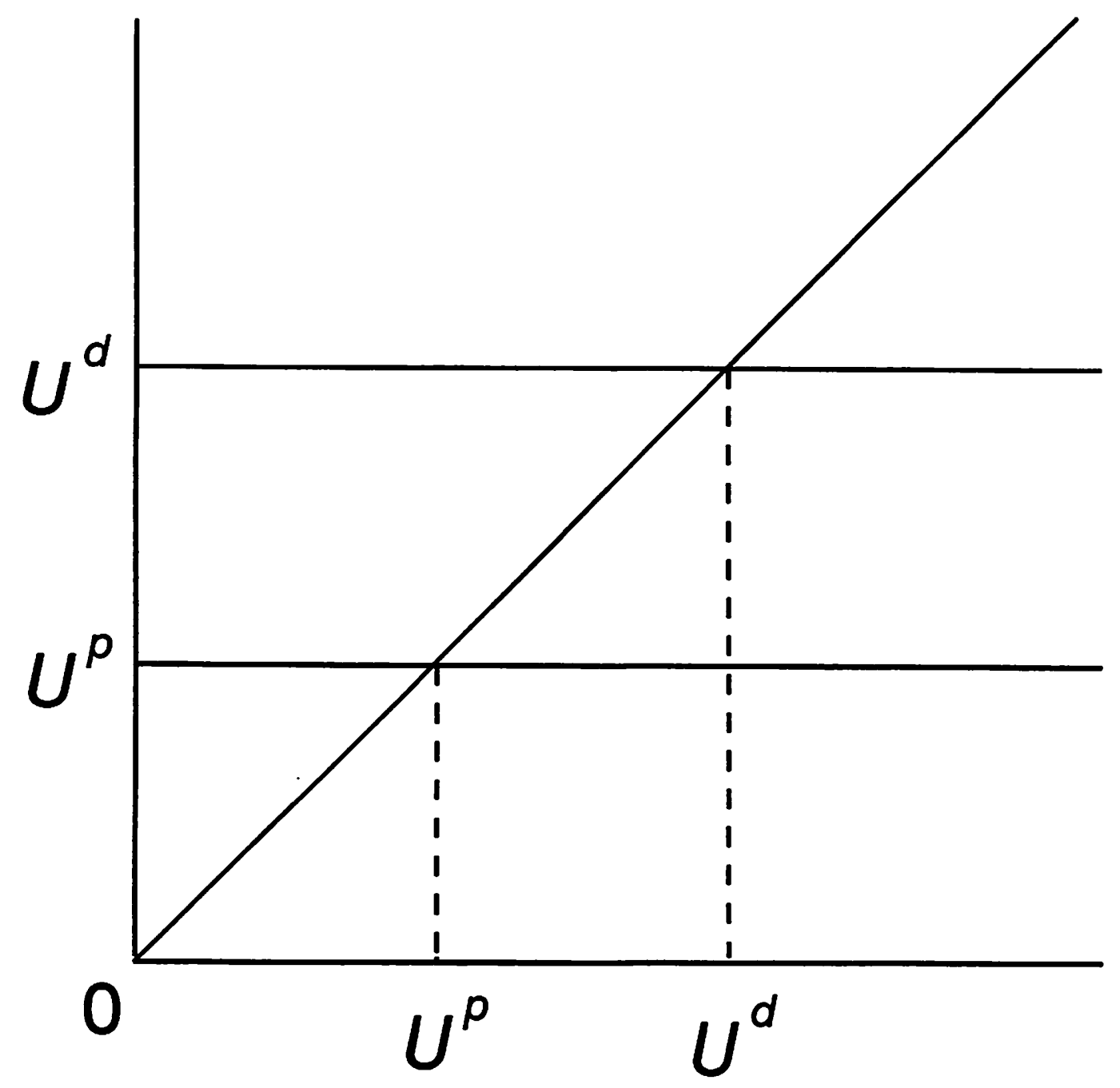

Offer

Figure 1 
Likewise, the relation between plaintiff's rejection of an offer and its gain from continuing to trial is given by the horizontal line at $U^{p}$. Observe that parties' expected loss and gain from trial do not vary with the offer in the absence of Rule 68 . The 45 degree line passing through the origin represents plaintiff's gain and defendant's loss from settlement. Thus, the size of the settlement range, $\left[U^{p}, U^{d}\right]$, will be equal to the litigation differential.

The standard definition of settlement range may not be directly applicable to the analysis of Rule 68 because, under the rule, parties can decide to go to trial both before and after an offer is made. To correct this problem, Miller provides an alternative definition of settlement range: settlement range is the set of offers that it would be rational for defendant to make and plaintiff to accept. ${ }^{21}$ Although this version incorporates parties' incentives to make and accept an offer, there are still several issues to be addressed before it can be applied. What does it mean by saying that it is rational for defendant to make an offer? Does it mean that making the offer is an optimal decision for the defendant? What are the alternative options available to the defendant other than making the offer? Is 'going to trial' the only alternative option? Does it suffice to show that the defendant has an incentive to make the offer and the plaintiff has an incentive to accept it?

In the absence of Rule 68, it is easy to construct a story under which Miller's definition of settlement range is consistent with the standard definition. Without Rule 68, the parties' expected gain or loss from trial is not affected by the fact that some party made an offer, nor by the amount of the offer. In the absence of Rule 68, it would be rational for the parties to settle the case for any offer that they would prefer to going to trial.22

Consider an offer $\hat{S}$ that is in the standard settlement range, $\left[U^{p}, U^{d}\right]$. Let us reexamine this offer in terms of the definition provided by Miller. Would it be rational for the plaintiff to accept the offer $\hat{S}$ ? The answer depends upon what his alternative 
option is. If the only alternative is going to trial (that is, if the plaintiff believes that there will be no further offers from the defendant), then accepting the offer would be his rational decision. Would it be rational for the defendant to make the offer $\hat{S}$ ? The answer depends not only on his alternative option, and but also on the plaintiff's response to the offer. Assume that the defendant understands the plaintiff's optimal response (which is to accept the offer $\hat{S}$ ). If the only alternative available to the defendant is going to trial (that is, if there will be no further opportunities to make more offers), then making the offer would be her rational decision. By specifying parties' alternative options in this way, the two definitions of settlement range can be shown to be consistent. The following definition that combines essential features of the two existing versions is used in this article, unless otherwise specified.

Definition 1. The (conventional) settlement range is the set of settlement offers that defendant has an incentive to make and that plaintiff has an incentive to accept when the only alternative available to the parties is going to trial.

An offer will be in the settlement range if the defendant prefers making it to going to trial and the plaintiff prefers accepting it to going to trial. It is straightforward to show that, in the absence of Rule 68, the settlement range in Definition 1 is equivalent to the one under the definition used in the standard model of litigation.

How does Definition 1 resolve the issue of which threat values are to be used in identifying the settlement range? For the defendant, the pre-offer threat value is a correct reference point because his incentive to make an offer has to be examined. For the plaintiff, however, the post-offer threat value for each rejected offer is a correct reference point because her incentive to accept or reject a given offer has to be examined. This may have a significant effect on the settlement of litigation under Rule 68 which is studied in the next subsection. 


\section{Settlement Incentives under Rule 68}

Now let us introduce Rule 68 into the picture. Rule 68, as noted, shifts the costs incurred after an offer of settlement to the plaintiff if the judgment ultimately obtained by the plaintiff is not more favorable than the offer. ${ }^{23}$ Before considering the defendant's incentive to make an offer and the plaintiff's incentive to accept it, examine, as a reference case, the case in which the defendant made an offer $S$ (nonnegative) and the plaintiff rejected it. Even in that case, there is nothing that precludes further negotiations or settlement (under Rule 68 or without it) between the parties. Recall that, in the absence of Rule 68 , the litigation differential has been defined as the difference between the defendant's loss from trial and the plaintiff's gain from trial. When a Rule 68 offer is rejected, the litigation differential at that offer can be called post-offer settlement range at that offer, because it determines the range of further offers that both parties would prefer to going to trial. ${ }^{24}$

When the plaintiff rejects an offer $S$ made by the defendant under Rule 68, both parties' loss and gain from trial will be reduced by the amount $z(S)$ which reflects the risk that the plaintiff may have to pay both parties' costs. The amount $z(S)$ is obtained by multiplying the probability that the plaintiff will win a judgment not more favorable than the offer by the sum of the parties' expected post-offer costs. Formally,

$$
z(S) \equiv(G(S)-G(0))\left(C^{p}+C^{ळ}\right)
$$

Note that $z(S)$ (weakly) increases with the offer $S$ and it also increases with the parties' costs $C^{p}$ and $C^{d}$.

Using the definition of $z(S)$, the plaintiffs expected gain from trial (after an offer $S$ is made and rejected) can be written as

$$
U^{p}(S) \equiv U^{p}-z(S)=\bar{x}-F^{p}-G(S)\left(C^{p}+C^{d}\right)
$$


The last term in (5) reflects the possibility that the plaintiff will suffer a cost-shifting penalty when the judgment is not more favorable than the offer. The probability that this will occur is equal to $G(S)$. Since this probability increases with the size of the offer, the plaintiff's gain from trial will be some decreasing function of the offer size.

The defendant's expected loss from trial under Rule 68 (after an offer $S$ is made and rejected) can be similarly expressed as

$$
U^{d}(S) \equiv U^{d}-z(S)=\bar{x}+F^{d}+(1-G(S))\left(C^{p}+C^{d}\right)
$$

The litigation differential under Rule 68 after an offer $S$ is made and rejected (or equivalently post-offer settlement range at $S$ ) can be identified as

$$
L D(S) \equiv U^{d}(S)-U^{P}(S)=U^{d}-U^{P}
$$

An offer of settlement under Rule 68 has no impact on the litigation differential for any given $S .{ }^{25}$ Thus, Rule 68 would not change the size of the post-offer settlement range for each offer. This remains true as long as both parties share the same beliefs on the litigation outcome.

To discuss the settlement range under Rule 68 , define two critical values of an offer. Define $\underline{S}$ by $U^{p}(S)=\underline{S}^{26}$ In words, it is the amount of settlement offer that makes the offer the same as plaintiff's gain from trial under Rule 68 after the offer was made and rejected. For a settlement offer smaller than $\underline{S}$, the plaintiff has an incentive to reject it and go to trial. Similarly, define $\bar{S}$ by $U^{d}(\bar{S})=\bar{S}$. In words, it is the amount of the settlement offer that makes the offer the same as the defendant's loss from trial under Rule 68 after the offer was made and rejected. For a settlement offer larger than 
$\bar{S}$, the defendant would be better off if the case goes to trial (after the offer is rejected) than if the case is settled with the offer. Since $U^{d}>U^{p}$, it can be shown that $\bar{S}>\underline{S} .{ }^{27}$

The Conventional Settlement Range. I claim that the conventional settlement range under Rule 68 consists of all offers $S$ satisfying $\underline{S} \leq S \leq U^{d}$. Recall that the defendant is the only party who is allowed to make a Rule 68 offer. Once an offer $S$ is made from the range $\left[S, U^{d}\right]$, the plaintiff would prefer settling with it to going to trial because $S \geq \underline{S}$. The defendant would prefer settling with the offer to going to trial without making any offer because $S \leq U^{d}$. Therefore, the range $\left[S, U^{d}\right]$ satisfies Definition 1.

Proposition 1. Assume that both parties have the same beliefs on litigation outcomes.

(i) The (conventional) settlement range under Rule 68 is $\left[\underline{S}, U^{d}\right]$.

(ii) The size of the settlement range (weakly) increases as a result of Rule 68. Proof. (i) As shown above.

(ii) From the definition of $\underline{S}$, we have $\underline{S} \equiv U^{p}-z(S) \leq U^{p}$ because $z(S) \geq 0$ for all $S$. The settlement range $\left[S, U^{d}\right]$ will be at least as large with Rule 68 as the settlement range $\left[U^{p}, U^{d}\right]$ without the rule because $U^{d}-\underline{S} \geq U^{d}-U^{p}$. Q.E.D.

\section{[Figure 2]}

This conclusion is illustrated in Figure 2. The defendant's expected loss from trial is $U^{d}$ when no offer is made but decreases along the line $U^{d}(S)$ as the amount of the offer increases (for simplicity a straight line is used to depict $U^{d}(S)$ ). Plaintiff's gain from trial, $U^{P}(S)$, shows a similar pattern. ${ }^{28}$ The 45 degree line passing through the origin represents plaintiffs gain and defendant's loss from settlement. The conventional settlement range under Rule 68 is $\left[\underline{S}, U^{d}\right]$, which is larger than the equivalent range without Rule 68; the increase in size is equal to $U^{d}-\bar{S}$. 
Gain/Loss

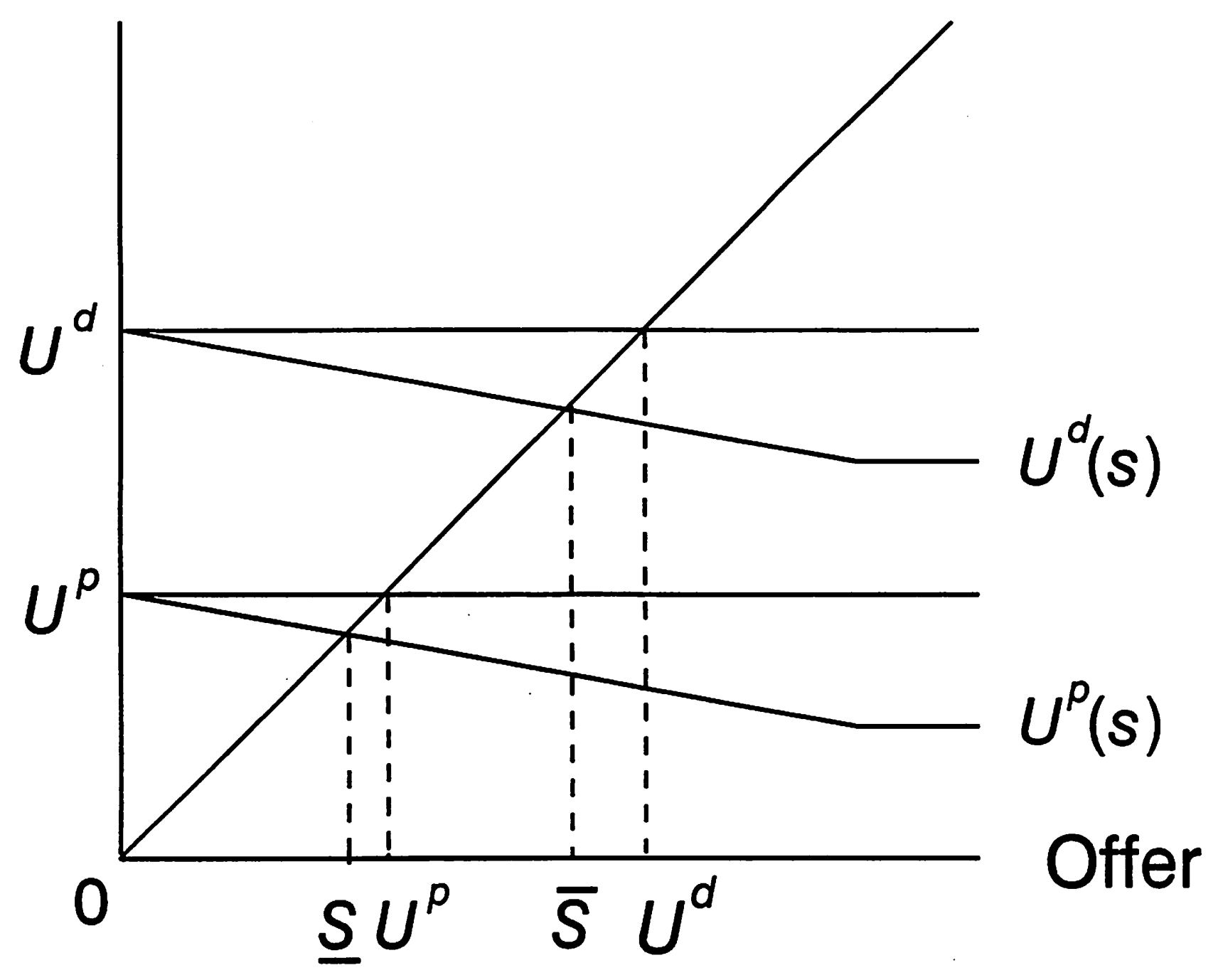

Figure 2 
The distinction between the settlement range with Rule 68 and the one without Rule 68 is their lower limits. With Rule 68, the lower limit is reduced because the plaintiff has an incentive to accept a lower offer to avoid potential cost-shifting under the rule. The upper limit does not change because the defendant still has an incentive to make an offer as long as it leads to a smaller expected loss than going to trial without making any offer. Therefore, the size of settlement range in general increases. ${ }^{29}$

The settlement range under Rule 68 in Proposition 1 is different from the settlement range identified in Miller's article. In Miller's article, the settlement range under Rule 68 is $[S, \bar{S}] .^{30}$ The distinction between Miller's settlement range and the settlement range in this article lies on the upper limits of the ranges. In particular, the issue boils down to whether offers between $\bar{S}$ and $U^{d}$ can be in the settlement range.

Suppose that the defendant has made an offer $S$ that is greater than $\bar{S}$, but less than $U^{d}$. At that offer, as Miller observes, the defendant would be better off going to trial with the offer rejected than settling with the offer accepted, because $S>U^{d}(S) .{ }^{31}$ It may be argued that settlement is not possible because the defendant prefers trial at that offer. The defendant cannot, however, directly control the plaintiff's decision to accept or reject an offer. What he can control is whether to make such an offer or not. Once such an offer is made, it is rational for the plaintiff to accept it. Since the defendant is better off with the offer accepted than without making any offer at all, it is possible for both parties to settle with the offer.

To show this formally, consider an offer $S^{*}$ satisfying $\bar{S}<S^{*}<U^{d}$. If such an offer $S^{*}$ is made by the defendant, it would be rational for the plaintiff to accept because $S^{*}>\bar{S} \equiv U^{d}(\bar{S})>U^{P}(\bar{S}) \geq U^{P}\left(S^{*}\right)$. Now the question is whether it would be rational for the defendant to make such an offer. If the defendant does not make the offer, his expected loss from trial is $U^{d}$. If he does make the offer, then his loss is $S^{*}$ because the offer will be accepted by the plaintiff. Since $S^{*}<U^{d}$, it would be rational 
for the defendant to make such an offer. This shows that the settlement offer $S^{*}$ is in the settlement range according to Definition 1.

\section{B. Effects of Rule 68 when parties' beliefs of litigation outcomes differ}

In this section, the assumption that both parties have the same assessment as to the probability distribution of litigation outcomes is relaxed. When parties' beliefs of litigation outcomes differ, it is shown by using Definition 1 that (i) settlement can be possible with Rule 68, while it is not possible without the rule, and (ii) settlement possibility is never destroyed as a result of Rule 68 . Let $G^{p}(\cdot)$ denote the plaintiff's probability distribution of litigation outcomes on its support $\left[0, K^{p}\right]$, and $\bar{x}^{p}$ denote his expected value of judgment, that is, $\bar{x}^{p} \equiv \int_{x d G^{p}}(x)$. For the defendant, similarly define $G^{d}(\cdot)$ on its support $\left[0, K^{d}\right]$, and $\bar{x}^{d}$. Let $K \equiv \max \left\{K^{d}, K^{p}\right\}$.

1. Settlement Incentives without Rule 68

In the absence of Rule 68, the plaintiffs expected gain from trial can be expressed as

$$
U^{p} \equiv \bar{x}^{p}-F^{p}-G^{p}(0)\left(C^{p}+C^{\phi}\right)
$$

Defendant's expected loss from trial can be similarly expressed as

$$
U^{d} \equiv \bar{x}^{d}+F^{d}+\left(1-G^{d}(0)\right)\left(C^{p}+C^{d}\right)
$$

From (8) and (9), the litigation differential is

$$
\begin{aligned}
L D \equiv U^{d}-U^{p}= & \left(F^{p}+F^{d}\right)+\left(C^{p}+C^{d}\right) \\
& +\left(\bar{x}^{d}-\bar{x}^{p}\right)+\left[G^{p}(0)-G^{d}(0)\right]\left(C^{p}+C^{d}\right)
\end{aligned}
$$


Compared to the litigation differential under symmetric beliefs in (3), the litigation differential in (10) will be smaller (can even be negative) if the plaintiff has more optimistic belief on judgment than the defendant has. ${ }^{32}$ Different beliefs affect the litigation differential in two ways. First, the plaintiffs expected value of judgment, $\bar{x}^{p}$, may exceed the defendant's expected value of judgment, $\bar{x}^{d}$. Second, the plaintiffs belief that he will lose the case, $G^{p}(0)$, is less than the defendant's belief, $G^{d}(0)$.

\section{Settlement Incentives under Rule 68}

To examine effects of Rule 68, the additional expected loss to the plaintiff created by Rule 68 (because he may have to pay both parties' costs) must be redefined as

$$
z^{p}(S) \equiv\left(G^{p}(S)-G^{p}(0)\right)\left(C^{p}+C^{\alpha}\right)
$$

For the defendant, the expected gain created by Rule 68 that the plaintiff may have to pay both parties' costs can be written as

$$
z^{d}(S) \equiv\left(G^{d}(S)-G^{d}(0)\right)\left(C^{p}+C^{d}\right)
$$

Using the definition of $z^{p}(S)$, the plaintiff's expected gain from trial after an offer $S$ is made and rejected can be written as

$$
U^{p}(S) \equiv U^{p}-z^{p}(S)=\bar{x}^{p}-F^{p}-G^{p}(S)\left(C^{p}+C^{\alpha}\right)
$$

The defendant's expected loss from trial under Rule 68 after an offer $S$ is made and rejected can be similarly expressed as 


$$
U^{d}(S) \equiv U^{d}-z^{d}(S)=\bar{x}^{d}+F^{d}+\left(1-G^{d}(S)\right)\left(C^{p}+C^{d}\right) .
$$

Litigation Differential. The litigation differential under Rule 68 after an offer $S$ is made and rejected (namely, post-offer settlement range at $S$ ) can be identified as

$$
\begin{aligned}
& L D(S) \equiv U^{d}(S)-U^{p}(S)=U^{d}-U^{p}+z^{p}(S)-z^{d}(S) \\
& \quad=\left(F^{p}+F^{d}\right)+\left(C^{p}+C^{d}\right)+\left(\bar{x}^{d}-\bar{x}^{p}\right)+\left[G^{p}(S)-G^{d}(S)\right]\left(C^{p}+C^{d}\right)
\end{aligned}
$$

The effect of Rule 68 on the size of the litigation differential is ambiguous. It depends on the exact shape of two probability distribution functions. ${ }^{33}$ In particular, it is determined by how the last term in (15) is affected when $S$ is changed from 0 to some positive offer. Depending on the distribution functions, the size of the litigation differential can be either increased or decreased as a result of Rule 68. It must be emphasized, however, that the possibility of settlement under Rule 68 cannot be directly determined by the size (or sign) of the litigation differential, because the litigation differential has been calculated on the assumption that an offer made by the defendant is rejected by the plaintiff. When an offer is such that it is optimal for the plaintiff to accept, the litigation differential may not be directly relevant in identifying settlement possibilities.

Settlement Range. To discuss the effects of Rule 68 on the settlement range when parties have different beliefs on litigation outcome, consider two special cases in which the effect is unambiguous. For clarity of exposition, assume that both parties have the same assessment as to the plaintiff's chance of prevailing at trial (that is, $\left.G^{p}(0)=G^{d}(0)\right)$. Note that, under this assumption, $L D=L D(K)$ because $z^{p}(K)=z^{d}(K)$ from $G^{d}(K)=G^{p}(K)=1$. In words, the assumption ensures that the litigation 
differential at zero offer (or no offer) is the same as the litigation differential at large offers that exceed $K$.

[Case 1]: If the plaintiff has more optimistic beliefs than the defendant (in the first-order stochastic dominance sense, that is, $G^{p}(S)<G^{d}(S)$ for all $\left.0<S<K\right)$, then the litigation differential is smaller under Rule 68 than without it. For example, if the litigation differential is negative without Rule 68 (no possibility of settlement), then under Rule 68, it will be still negative and the gap will become even bigger for any given $S$ (See Figure 3). It has been argued in the existing literature that settlement is not possible in that case because the litigation differential is negative under Rule $68 .{ }^{34}$ When the parties' incentives to make and accept an offer are considered, however, settlement can be possible. Figure 3 illustrates the case in which settlement could become possible under Rule 68 even though it would be impossible in the absence of the rule.

[Figure 3]

Recall that, in Case 1, if the plaintiff has more optimistic beliefs than the defendant, the litigation differential is smaller under Rule 68 than without it. There could be cases in which the litigation differential in the absence of a Rule 68 offer was positive but in which, as a result of the rule, the litigation differential becomes negative. Does that mean that settlement becomes impossible as a result of Rule 68 ? The answer will be negative if the conventional settlement range is used. Figure 4 illustrates this case. In Figure 6, the litigation differential in the absence of a Rule 68 offer is positive because $U^{d}>U^{p}$. According to Miller's argument, settlement becomes impossible because $\bar{S}<\underline{S}$. When Definition 1 is used to identify a settlement range, however, the settlement range is $\left[S, U^{d}\right]$, and thus settlement continues to be possible. 


\section{Gain/Loss}

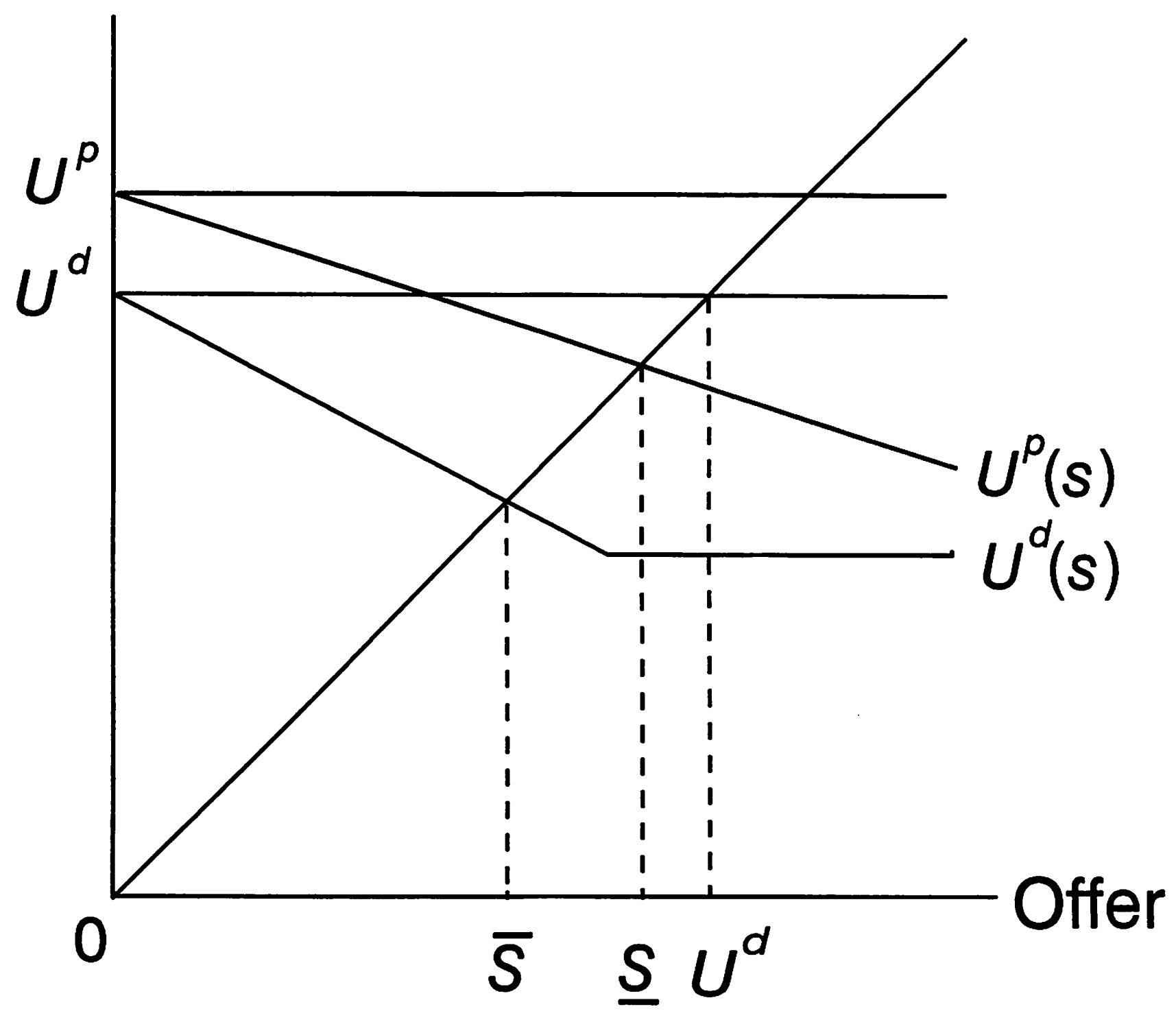

Figure 3 
[Figure 4]

[Case 2]: If the defendant has more optimistic beliefs than the plaintiff (that is, $G^{d}(S)<G^{p}(S)$ for all $\left.0<S<K\right)$, then the litigation differential is larger under Rule 68 than without it. In this case, we must have $\bar{x}^{d}>\bar{x}^{p}$, which implies that $U^{d}>U^{p}$. This is illustrated in Figure 5, in which the size of the settlement range increases from $\left[U^{p}\right.$, $\left.U^{d}\right]$ to $\left[S, U^{d}\right]$ as a result of Rule 68 .

[Figure 5]

Case 2 suggests that, with more general distribution functions, there could be cases in which a settlement becomes possible as a result of Rule 68. In Figure 6, the litigation differential in the absence of a Rule 68 offer is negative because $U^{p}>U^{d}$, and thus settlement is not possible. According to the argument made in this article, however, settlement becomes possible because the settlement range following Definition 1 is $\left[S, U^{d}\right] .^{35}$

[Figure 6]

Let me summarize these discussions. When settlement is possible in the absence of Rule 68, settlement is also possible under Rule 68. Rule 68 never destroys the possibility of settlement that exists in the absence of the rule. The rule, however, can create new settlement possibilities that do not exist in the absence of the rule. Suppose that, in the absence of an offer under Rule 68, settlement is not possible because plaintiff's expected gain from trial exceeds the defendant's expected loss from trial, that is, $U^{p}>U^{d}$. Define $\underline{S}$ as before by $U^{p}(S)=\underline{S}$. Assume that $U^{d}>U^{p}(\underline{S})$, that is, $z^{p}(S)>U^{p}-U^{d}$. In words, potential loss due to the risk of paying both parties' costs 
Gain/Loss

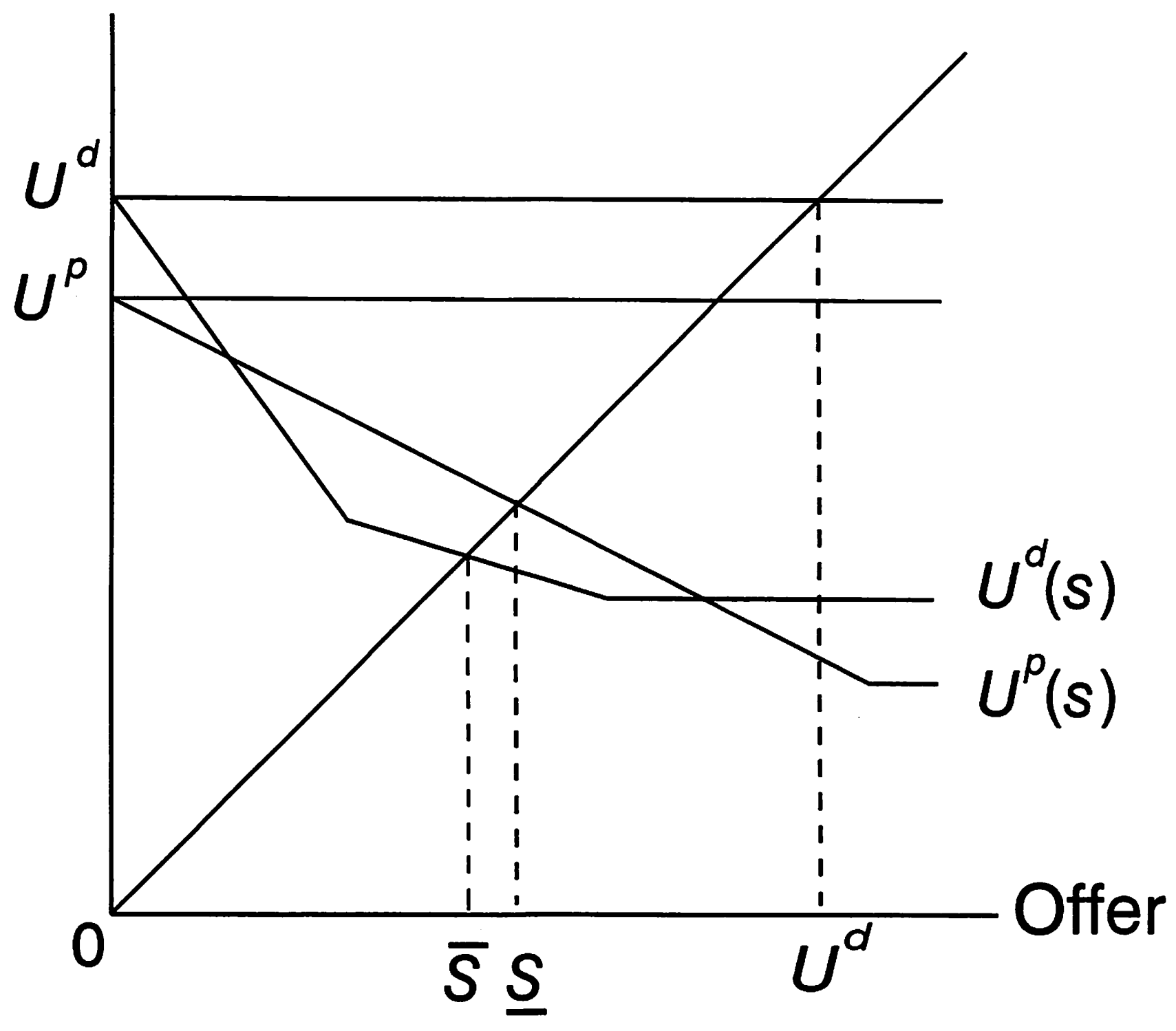

Figure 4 


\section{Gain/Loss}

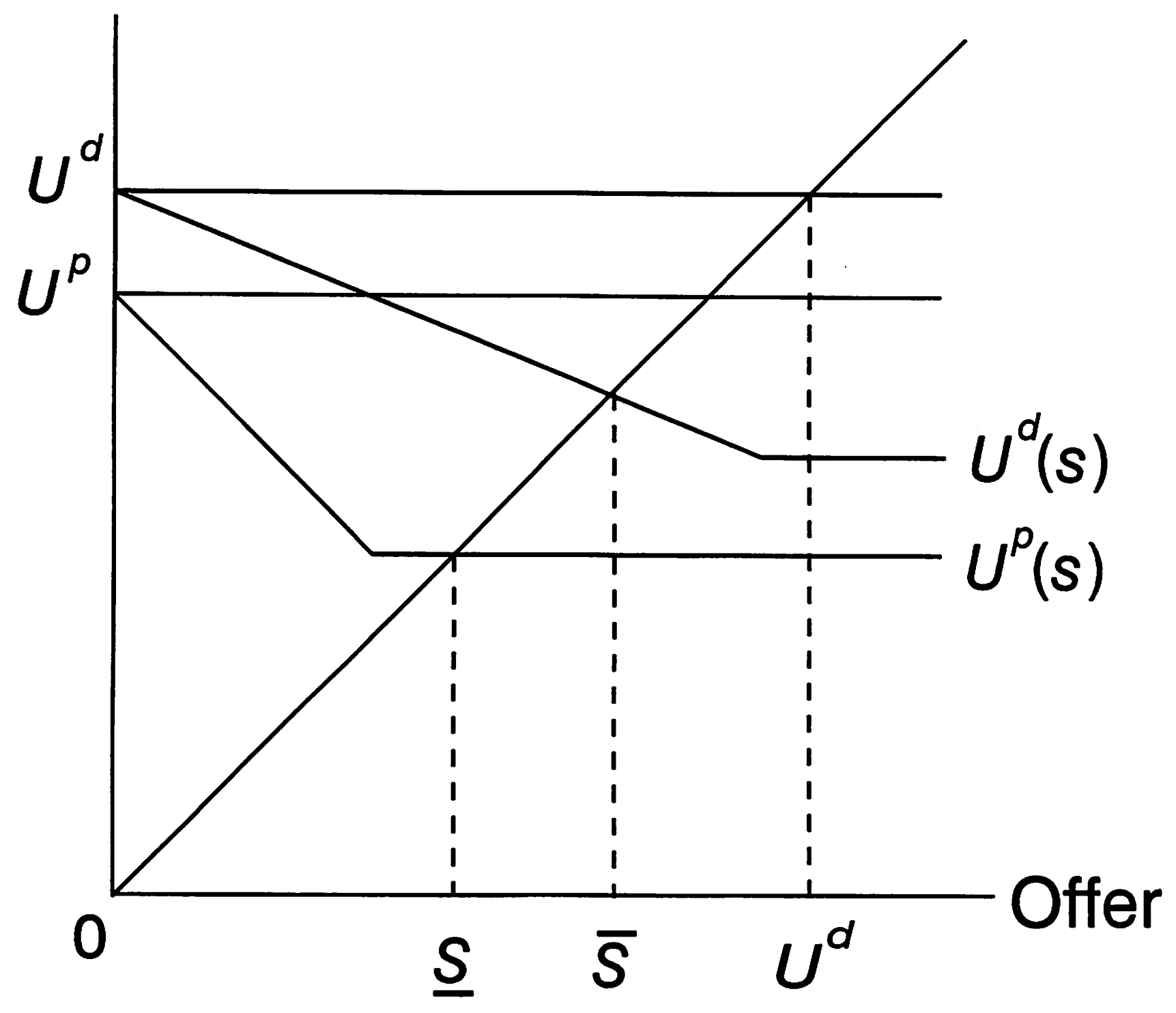

Figure 5 


\section{Gain/Loss}

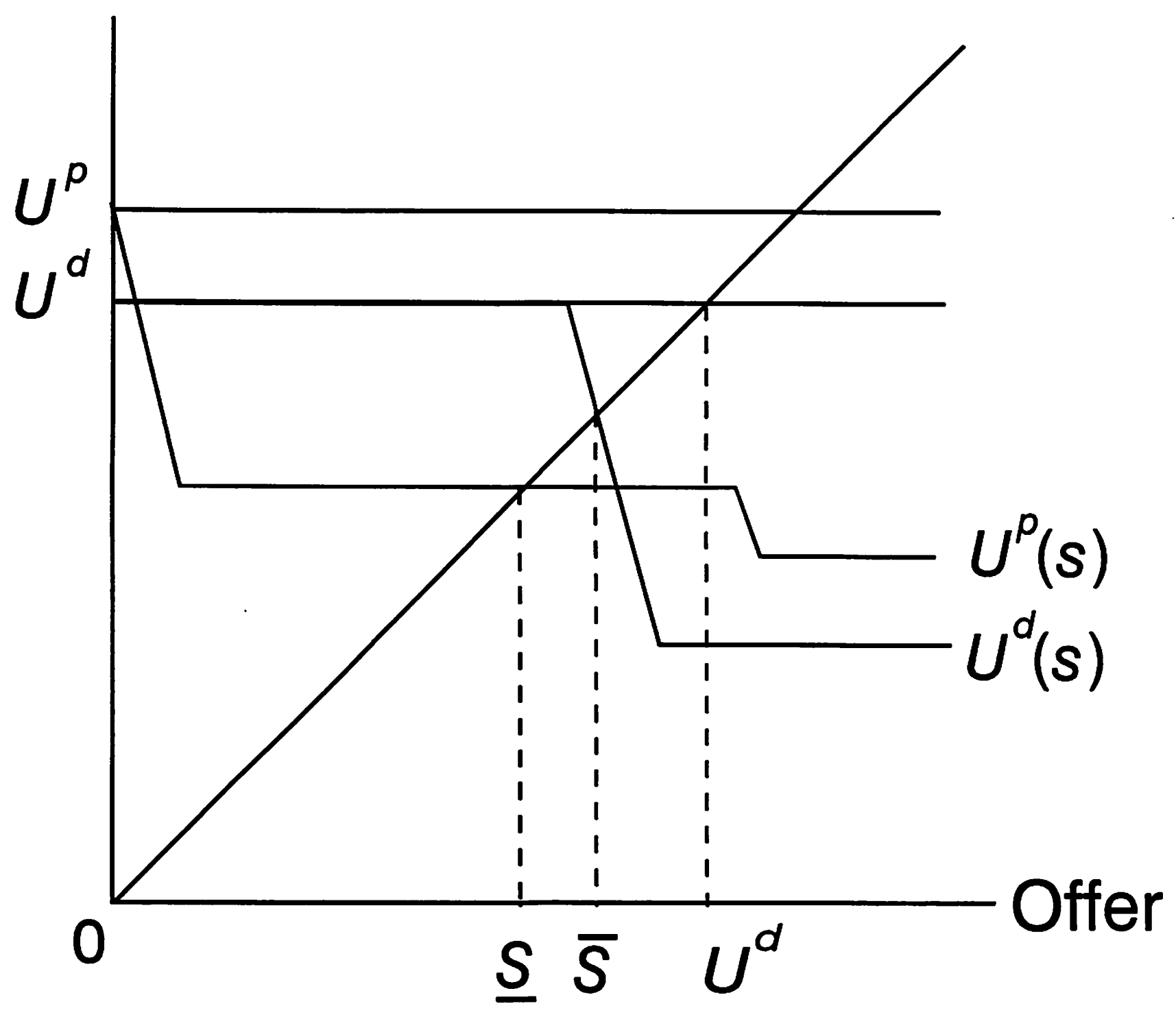

Figure 6 
under Rule 68 is large enough to outweigh the plaintiff's relative optimism. According to the argument in the present article, the settlement range with Rule 68 is $\left[\underline{S}, U^{d}\right]$ which is non-empty. In such situations, settlement would become possible under Rule 68 even though it would be impossible in the absence of the rule.

\section{A Numerical Example ${ }^{36}$}

Consider a suit for breach of contract in which the contract damages are estimated at $\$ 100,000$. If the plaintiff litigates the case to judgment at trial, plaintiff's attorney fees will total $\$ 20,000$. The costs of taking the case to judgment at trial are expected to be $\$ 1,500$ for the plaintiff and $\$ 2,500$ for the defendant. The plaintiff has a 90 percent chance of prevailing on liability at trial. In the absence of Rule 68, the plaintiffs gain from trial is then $(.9 \times \$ 100,000)-\$ 20,000-(.1 \times \$ 4,000)$, or $\$ 69,600$. Assume that the defendant's expected fees are only $\$ 10,000$. Then, the defendant's loss from trial is $(.9 \times \$ 100,000)+\$ 10,000+(.9 \times \$ 4,000)$, or $\$ 103,600$. In the absence of Rule 68 , thus, the settlement range would be the set of offers from $\$ 69,600$ to $\$ 103,600$, for a total range of $\$ 34,000$.

Now let us introduce Rule 68 into the picture. Let $Q$ denote the probability that the plaintiff will obtain a judgment exceeding the amount of the settlement offer. For simplicity, consider $Q=1-$ offer $/ \$ 150,000$. With this specification of $Q$, Miller shows that the settlement range is determined by the minimum offer $\$ 68,181$ and The maximum offer $\$ 101,300$. Thus the settlement range under Rule 68 is approximately $\$ 33,119$. This range is obtained by calculating the parties' expected payoffs from trial given that an offer is already made. To illustrate it, consider the maximum offer $\$ 101,300$. If the settlement offer is slightly less than the maximum, then the defendant's expected loss from trial exceeds the settlement offer. In that case, the defendant is willing to make such an offer, which far exceeds the plaintiff's gain from 
trial. On the other hand, if the settlement offer is greater than the maximum, the defendant's expected jloss from trial at that offer will be less than the offer. Since the defendant prefers going to trial, the offer is not in the settlement range.

This last point, however, ignores the plaintiffs incentive to accept the settlement offer. I claim that if an offer that is strictly between $\$ 101,300$ and $\$ 103,600$ is made, then it would be rational for the plaintiff to accept, and furthermore that it would be rational for the defendant to make such an offer. If the defendant does not make an offer, his loss from trial is $\$ 103,600$ (Rule 68 does not have any effect), whereas if he makes such an offer that will be accepted by the plaintiff, then his loss is only the amount of the offer that is less than $\$ 103,600$ by construction. Therefore, the defendant is better off with such an offer. The correct settlement range is the set of offers from $\$ 68,181$ to $\$ 103,600$, for a total range of $\$ 35,419$. The settlement range expands by $\$ 1,419$ with Rule 68 .

To illustrate the case in which the settlement is possible with Rule 68, while it is not possible without the rule, let us modify the numerical example. Suppose that the plaintiff believes that he would prevail with a 90 percent chance, while the defendant believes that the plaintiff would prevail with a 57 percent chance. The plaintiff's expected gain from trial in the absence of Rule 68 remains at $\$ 69,600$ as before. The defendant's loss from trial is $(.57 \times \$ 100,000)+\$ 10,000+(.57 \times \$ 4,000)$, or $\$ 69,280$. In the absence of Rule 68, the settlement range does not exist because the litigation differential is negative. Now let us introduce Rule 68 into the picture. Using the same distribution, $Q=1$ - offer $/ \$ 150,000$, the lower limit of the settlement range $\underline{S}$ can be calculated at $\$ 68,181$ as before. According to the present analysis, the new settlement range under Rule 68 is $[\$ 68,181, \$ 69,280]$. For example, the defendant is willing to make an offer of $\$ 68,400$ because the amount is less than the loss from trial she would expect if she does not make an offer. The plaintiff is willing to accept it because the offer exceeds the gain from trial that he would expect if he rejects the offer. 


\section{RULE 68 AND THE REFINED SETtLEMENT RANGE}

In the previous section, the conventional settlement range under Rule 68 is identified by using Definition 1. In examining whether an offer is in the settlement range, Definition 1 requires only a comparison between an offer and parties' positions at trial. It does not require a comparison among different offers. There may be cases in which an offeror does not have an incentive to make a certain offer because he is always better off by making a different offer even if both offers are in the conventional settlement range. Therefore, Definition 1 may not necessarily result in the settlement range that indicates the true settlement possibilities under Rule 68.

It is shown that the conventional settlement range could contain offers that are 'dominated' in a sense that will be specified shortly. A good definition of a settlement range should not include such 'dominated' offers because the parties will never be able to settle with the offers. In this section, a definition of the refined settlement range is introduced by eliminating all dominated offers from the conventional settlement range, and its implication is discussed.

\section{A. Refinement of Settlement Range.}

To examine the dominance argument, consider an offer $S_{1}$ to which acceptance is the plaintiff's best response. With the offer, the defendant's expected loss in equilibrium is $S_{1}$. Consider another offer $S_{2}$ that is less than $S_{1}$. If the maximum loss to the defendant with the offer $S_{2}$ is less than $S_{I}$ (regardless of the possibility of further negotiation after the offer is rejected), then it can be said that $S_{1}$ is dominated by $S_{2}$ for the defendant. In that case, the defendant does not have any incentive to make the 
dominated offer $S_{1}$ at all. Such a dominated offer should be eliminated from a welldefined settlement range that can indicate true settlement possibilities.

Offers in the disputed range, $\left(\bar{S}, U^{d}\right]$, are natural candidates for such dominated offers. Consider an offer $S^{0}$ that is greater than $\bar{S}$, and less than or equal to $U^{d}$. The defendant's expected loss in equilibrium (when he makes the offer) is $S^{\circ}$, because the plaintiff's best response to the offer is accepting it. It is claimed that the defendant would be better off by instead offering $\bar{S}$. It is claimed that if the defendant offers $\bar{S}$, his maximum loss will be $\bar{S}$, regardless of the plaintiff's response. If plaintiff accepts the offer of $\bar{S}$, the defendant's loss will be $\bar{S}$. If the plaintiff rejects $\bar{S}$, then the worst case for the defendant will be going to trial with an expected loss of $\bar{S}$. If parties can settle by themselves (after the plaintiff rejects the original offer $\bar{S}$ ), the defendant will do better, not worse. Since the defendant's expected loss by making the offer $S^{0}$ is greater than his maximum expected loss by making the offer $\bar{S}$, the defendant can lower his expected loss by offering $\bar{S}$, instead of $S^{o}$. Therefore, it can be argued that the defendant does not have any incentive to make offers in the range $\left(\bar{S}, U^{d}\right]$.

Definition 2. An offer $S_{1}$ is equilibrium-dominated for a player if there exists another offer $S_{2}$ such that the minimum payoff the player can obtain by offering $S_{2}$ is greater than the equilibrium payoff he will obtain by offering $S_{1}$ (given that the other player will choose his optimal response).

Definition 2 says that if the worst that one can expect with $S_{2}$ is better than the equilibrium payoff with $S_{1}$, then $S_{1}$ is equilibrium-dominated for the player. For the defendant whose objective is to minimize expected losses, $S_{1}$ is equilibriumdominated if there exists $S_{2}$ such that the maximum loss with $S_{2}$ is less than the equilibrium loss with $S_{1}$. 
Definition 3. The equilibrium-refined settlement range is the set of offers that can be obtained by eliminating all offers that are equilibrium-dominated from the conventional settlement range.

Note that in the absence of Rule 68, refinement based on the equilibrium domination argument does not have any bite on the conventional settlement range. Under Rule 68, however, the conventional settlement range can be refined by eliminating equilibrium-dominated offers.

Proposition 2. The equilibrium-refined settlement range under Rule 68 is $[S, \bar{S}]$. Proof. See the Appendix.

In Proposition 2, the equilibrium-refined settlement range $[S, \bar{S}]$ can be an empty set even if the conventional settlement range $\left[\underline{S}, U^{d}\right]$ is non-empty. Figure 3 and Figure 4 illustrate such a case. ${ }^{37}$

Proposition 2 confirms the intuitive argument made in the existing literature that Rule 68 does not increase settlement range. In particular, all of Miller's results are consistent with this refined settlement range, because the settlement range identified in Miller's article is identical to the equilibrium-refined settlement range. Although there could be unusual cases in which settlement possibilities are destroyed as a result of Rule 68 (see Figure 4), and in which settlement possibilities are created as a result of the rule (see Figure 6), its most significant effect is to redistribute wealth from plaintiff to defendant. 


\section{A Proposed ReVISION of RULE 68}

In the previous Section II, the standard argument that Rule 68 does not expand the possibility of settlement is confirmed with an appropriate refinement of the conventional settlement range. In Section I, however, Rule 68 is shown to expand the settlement range in its unrefined, conventional sense. Suppose that encouraging settlement is a policy goal to pursue. ${ }^{38}$ Is there any way to revise the current Rule 68 to increase settlement possibilities? In Subsection A, based upon the analysis of Section I, a proposal for revising Rule 68 is presented to create new settlement possibilities without destroying any existing settlement possibilities. ${ }^{39}$ In Subsection $B$, a sufficient condition under which the settlement range expands under the proposed revision is identified. In Subsection C, the effect of Rule 68 on the plaintiff's incentive to bring suit is examined.

\section{A. Proposed revision of Rule 68 and settlement range}

Rule 68 is intended to encourage settlements by taxing aggressive plaintiffs, which seems to expand the (conventional) settlement range as shown in Section I. When the defendant's incentive to make an offer is carefully considered, however, its effect on settlement is ambiguous, as reflected in the equilibrium-refined settlement range in Section II. This is because under Rule 68 the defendant does not have an incentive to make large offers. Is there any way to guarantee that settlement range expands without shrinking? How can Rule 68 be revised to discipline an aggressive plaintiff without creating a perverse incentive for a defendant?

It is shown that if the current Rule 68 is revised in a way that the plaintiff who lost against the defendant's offer pays the defendant's post-offer costs to a third party, not to the plaintiff, then the settlement range will be expanded. This separation helps 
maintain the intended effect of the rule in punishing aggressive plaintiffs, and at the same time helps prevent its perverse effect on the defendant's incentive to make offers. ${ }^{40}$

The formal analysis of the effects of this proposed revision is not detailed here because it would be quite similar to the one presented in Section I. Under the proposal, the defendant's expected loss remains the same at $U^{d}$ regardless of the size of the rejected Rule 68 offers. Therefore, it is obvious that the conventional settlement range under the proposal is $\left[\underline{S}, U^{d}\right]$. This conclusion is illustrated in Figure 7.

\section{[Figure 7]}

An interesting issue is whether the refinement used in Section II has any bite under the proposal. It is shown that it does not have any effects as the proposed rule does not prevent the defendant from making large offers. Therefore, the equilibriumrefined settlement range is identical to the conventional settlement range under this proposal. This is summarized in the following proposition.

Proposition 3. Suppose the current Rule 68 is revised in a way that the plaintiff who lost against the defendant's offer pays the defendant's post-offer costs to a third party, not to the plaintiff.

(i) The conventional settlement range is $\left[S, U^{d}\right]$.

(ii) The equilibrium-refined settlement range also is $\left[S, U^{d}\right]$. Proof. Omitted.

It may be argued that under the proposed revision, the defendant may not have an incentive to make a Rule 68 offer because he will not benefit directly when the losing plaintiff pays costs to the third party, not to the defendant. Although there is no 


\section{Gain/Loss}

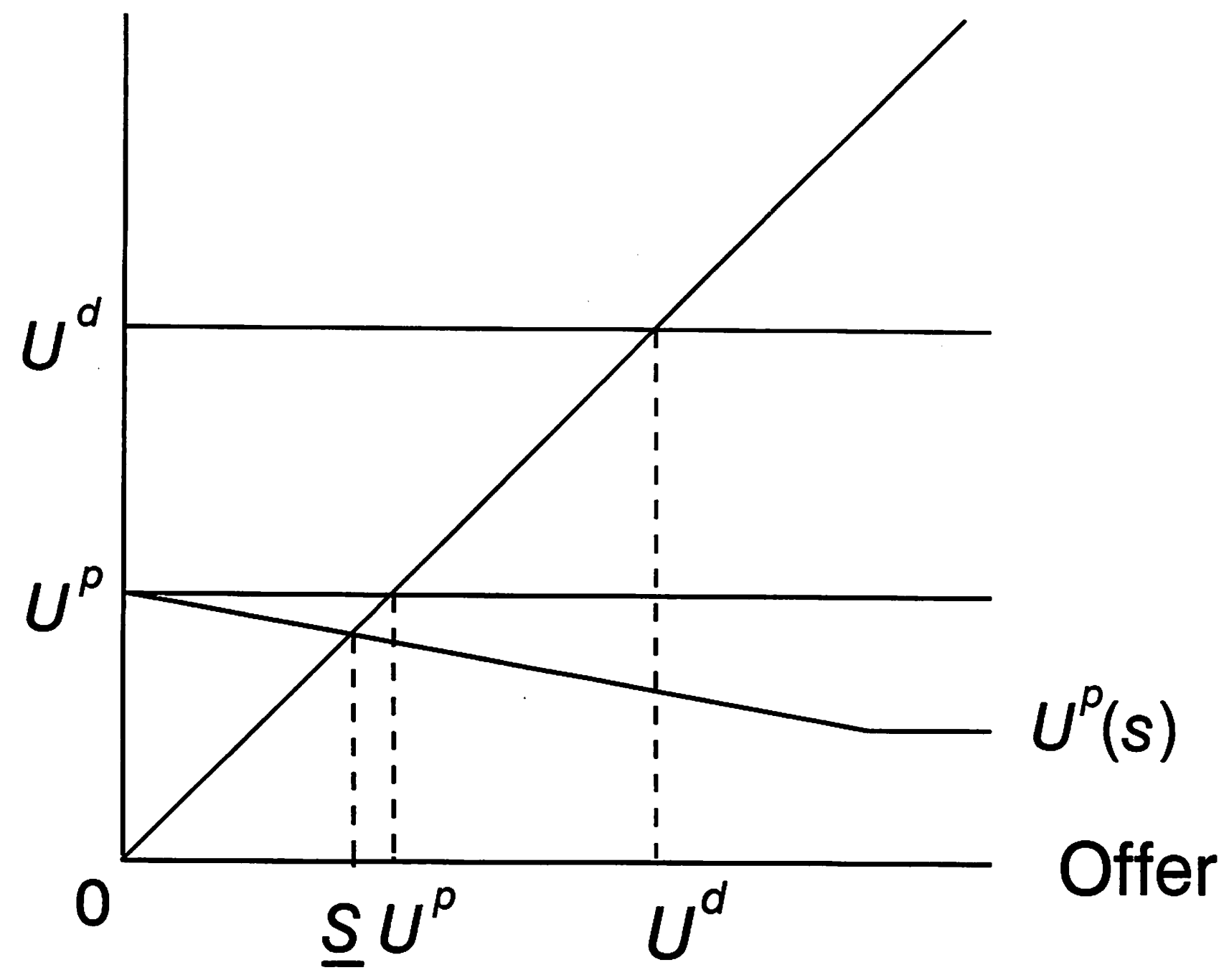

Figure 7 
direct monetary transfer between the parties due to the rule, the defendant still is better off as a result of the revised Rule 68 , because the plaintiff is willing to accept smaller offers, and thus the defendant's expected losses can be smaller.

Under the proposed revision, the size of the settlement range (both conventional and refined) weakly increases as a result of Rule 68 (See Proposition 1, (ii)). It would be useful to identify conditions under which the size of the settlement range strictly increases, which is the subject of the following subsection.

\section{B. When is Rule 68 operative? ${ }^{41}$}

Does the settlement range always expand with Rule 68? In order for Rule 68 to be operative, it is essential that the plaintiff's belief is such that the amount of judgment is quite uncertain. Take, for example, a suit in tort under negligence rule. When actual loss to victim is certain and easily verifiable, the only uncertainty is whether the defendant is liable or not. In such a circumstance, Rule 68 does not have any effects on the parties' incentive to settle. This may explain why Rule 68 has not been much used in practice.

To identify a sufficient condition under which Rule 68 is operative (that is, a condition under which it expands settlement range), first consider the case in which a settlement range exists even without Rule 68. In that case, a required condition is that the plaintiff believes that there is a positive probability that the judgment amount is strictly between zero and $U^{p}$. Under the condition, if the plaintiff rejects a settlement offer $U^{p}$, he faces the risks of paying both parties' costs. Thus, he prefers accepting the offer to rejecting it. By continuity, he is willing to accept an offer that is slightly smaller than $U^{p}$. Formally, when $z^{p}\left(U^{p}\right)=\left(G^{p}\left(U^{p}\right)-G^{p}(0)\right)\left(C^{p}+C^{d}\right)>0$, we have $\underline{S}<$ $U^{P}$ from the definition of $\underline{S}$. 
Next, consider the case in which the settlement range does not exist without Rule 68 , that is, $U^{p}>U^{d}$. In this case, the plaintiffs potential loss from the risk of paying both parties' costs under Rule 68 must be large enough to outweigh the initial difference $U^{p}-U^{d}$. Formally, we need $z^{p}(S)=\left(G^{p}(S)-G^{p}(0)\right)\left(C^{p}+C^{d}\right)>U^{p}-U^{d}$.

Proposition 4. Rule 68 is operative, that is, it strictly expands the (proposed) settlement range under one of the following conditions:

(i) $U^{d} \geq U^{p}$, and $G^{p}\left(U^{p}\right)-G^{p}(0)>0$.

(ii) $U^{d}<U^{p}$, and $G^{p}\left(U^{d}\right)-G^{p}(0)>\left(U^{p}-U^{d}\right) /\left(C^{p}+C^{d}\right)$.

Proof. See the Appendix.

A direct consequence of Proposition 4 is that when litigation outcome is dichotomous, Rule 68 is inoperative. Litigation outcome is dichotomous if the plaintiff thinks he has a certain chance $(1-p)$ of losing (that is, winning zero) and a remaining chance $p$ of winning a fixed amount $J$. The plaintiff's gain from trial without any Rule 68 offer, $x^{p}$, is equal to $J P$. Note that $0<x^{p}<J$ for any $p<1$. Since the plaintiff does not believe the possibility that judgment is greater than zero and less than $J$, it can be shown that $z(S)=0$ for any $S<J$. Therefore, $\underline{S}=U^{p}$, and the settlement range does not change with Rule $68 .{ }^{42}$

Corollary. If litigation outcome is dichotomous, Rule 68 is inoperative.

Proof. It suffices to show that $G^{p}\left(U^{p}\right)-G^{p}(0)=0$, which violates both conditions (i) and (ii) in Proposition 4. By assumption, $0 \leq U^{p}$, and from (8), $U^{p}<\bar{x}^{p}$. Therefore, $G^{p}(0) \leq G^{p}\left(U^{p}\right) \leq G^{p}\left(\bar{x}^{p}\right)$. Since $0<x^{p}<J$ for any $p<1, G^{p}\left(\bar{x}^{p}\right)=G^{p}(0)$. Hence, we obtain $G^{p}\left(U^{P}\right)=G^{P}(0)$. Q.E.D. 
A related issue is how parameters of the model affect the size of the settlement range. It is straightforward to see that the increase in $C^{p}$ and $C^{d}$ will strengthen the effect of Rule 68 in increasing the size of the settlement range. The greater the size of taxable costs, the smaller is the amount of an offer that the plaintiff is willing to accept. It can be easily shown from this observation that including reasonable amounts of attorney's fees as a taxable item will strengthen the effect of Rule 68 on increasing the settlement range. The plaintiff's belief also matters. For example, if the plaintiffs belief of the litigation outcome becomes more optimistic, then the effect of expanding the settlement range of the rule is smaller.

\section{Plaintiff's incentive to bring suit}

One potential problem of Rule 68 has been its effect on the plaintiff's incentive to bring suit. It has been argued that a meritorious plaintiff who would bring suit may not have an incentive to bring suit as a result of Rule 68 because he is facing the risks of paying both parties' costs. ${ }^{43}$ It is shown that the plaintiff's incentive to bring a suit is not affected with (both current and proposed) Rule 68.

In the absence of Rule 68, the plaintiff has an incentive to bring suit if $U^{P}$ is positive. When $U^{P}$ is negative, the plaintiff's threat of going to trial is not credible. In that case, the defendant knows that it would not be in the plaintiff's best interest to go to trial in the absence of a settlement, and thus the defendant's best strategy is to refuse any settlement. Given this response, the plaintiff does not have any incentive to bring suit in the first place because $U^{p}$ is negative.

Under Rule 68, the risks imposed on the plaintiff of paying both parties' costs may be so large that although $U^{p}$ is positive, the plaintiff's post-offer expected payoff, $U^{P}(S)$, can be negative for some offer $S$. Suppose that there exists such an offer, say $S^{2}$, such that $U^{P}\left(S^{2}\right)<0$. Since $U^{P}$ is positive, $S^{2}$ must be positive. If the defendant 
makes the offer $S^{2}$, the plaintiff's best response would be accepting it so that his expected gain is positive. Hence, his incentive to bring suit is not diminished.

Under Rule 68, the plaintiff has an incentive to bring suit if $U^{P}(S)$ is positive. The plaintiff can guarantee her expected gains to be at least as large as $U^{P}(S)$ by rejecting any offer that is less than $\underline{S}$, and by accepting any other offer. If the defendant does not make any offer, her expected gain from trial remains at $U^{p}$ that is greater than or equal to $U^{p}(S)$. Even if the defendant has all the bargaining power in settlement, the defendant cannot make the plaintiffs expected gain to be less than $U^{P}(S)$.

Proposition 5. The plaintiff's incentive to bring suit is not affected with Rule 68. If the plaintiff has an incentive to bring suit in the absence of Rule 68, she still has an incentive to bring suit under Rule 68. Formally, if $U^{P}>0$, then $U^{P}(S)>0$.

Proof. Assume that $U^{p}>0$. It suffices to show that $\underline{S}>0$ because $\underline{S} \equiv U^{P}(S)$. Suppose to the contrary that $\underline{S} \leq 0$. From the definition of $z^{p}(S)$ in $(11)$, we have $z^{p}(S) \equiv\left(G^{p}(S)\right.$ $\left.G^{p}(0)\right)\left(C^{p}+C^{d}\right)=0$ for $\underline{S} \leq 0$. Using the definition of $U^{p}(S)$ in (13), we have $\underline{S} \equiv U^{p}(S)$ $=U^{p}-z^{p}(S)=U^{p}$. Hence, if $U^{p}>0$, then $\underline{S}>0$, which contradicts to the hypothesis that $\underline{S} \leq \mathbf{0} \quad$ Q.E.D.

\section{CONCLUSION}

This article has studied the economic effects of Rule 68 by identifying settlement possibilities with a particular focus on the parties' incentive to make and accept an offer. An economic analysis is provided to show that (i) the standard definition of settlement range is inadequate for analyzing Rule 68, (ii) a refinement of the conventional settlement range is needed to confirm the intuition that Rule 68 does not increase settlements, and (iii) the proposed revision of Rule 68 enhances 
settlements of litigation. It also is shown that Rule 68 is inoperative for all cases in which the litigation outcome is dichotomous, and that the rule does not diminish the plaintiffs incentive to bring suit.

This article examines cases in which the default rule of allocating litigation costs is the modified American rule. It is conjectured that the basic idea can be extended to cases in which the default rule is the pure American Rule. ${ }^{44}$ It would be interesting to study whether the approach taken in this article has any effects on our evaluation of several proposed amendments of Rule 68. For example, a detailed analysis of a mutual cost-shifting rule under different default rules would be a promising research agenda. 


\section{APPENDIX}

The appendix includes proofs of Proposition 2 and Proposition 4.

Proposition 2. The equilibrium-refined settlement range is $[\underline{S}, \bar{S}]$.

Proof. As discussed in the text preceding the proposition, all offers in $\left(\bar{S}, U^{d}\right]$ are equilibrium-dominated for the defendant by $\bar{S}$. Therefore, it suffices to show that no offer in $[S, \bar{S}]$ is equilibrium-dominated for the defendant. If the range $[S, \bar{S}]$ is either an empty set or a singleton set, then the last statement is vacuously true. Otherwise, fix an offer $\hat{S}$ in $[S, \bar{S}]$. The equilibrium loss to the defendant with the offer is $\hat{S}$ because the plaintiff has an incentive to accept it.

First, it is shown that $\hat{S}$ cannot be equilibrium-dominated by any offer, say $S_{3}$, that is greater than $\hat{S}$. This is true because the maximum loss with $S_{3}$ is $S_{3}$ when the offer will be accepted by plaintiff.

Second, it is shown that $\hat{S}$ cannot be equilibrium-dominated by any offer that is less than $\hat{S}$. Since $U^{d}(S)$ is decreasing in $S$, we obtain that (i) $U^{d}(S) \geq U^{d}(\hat{S})$ for all $S<$ $\hat{S}$, and that (ii) $U^{d}(\hat{S}) \geq \hat{S}$ from $\hat{S} \leq \bar{S}$ and from $U^{d}(\bar{S}) \equiv \bar{S}$. From (i) and (ii), we obtain $U^{d}(S) \geq \hat{S}$ for all $S<\hat{S}$. In other words, for all $S<\hat{S}$, post-offer settlement range at $S$ contains an offer that exceeds $\hat{S}$ which is the equilibrium payoff with the offer $\hat{S}$. The maximum loss under such offer $S$ cannot be lower than the equilibrium loss with $\hat{S}$. Therefore, $\hat{S}$ cannot be equilibrium-dominated by any offer that is less than $\hat{S}$. Q.E.D. 
Proposition 4. Rule 68 is operative, that is, it strictly expands the settlement range under one of the following condition:

(i) $U^{d} \geq U^{p}$, and $G^{p}\left(U^{p}\right)-G^{p}(0)>0$.

(ii) $U^{d}<U^{p}$, and $G^{p}\left(U^{d}\right)-G^{p}(0)>\left(U^{p}-U^{d}\right) /\left(C^{p}+C^{d}\right)$.

Proof. (i) From the definition of $\underline{S}$, we have $\underline{S} \equiv U^{p}-z^{p}(S) \leq U^{p}$ because $z^{p}(S) \geq 0$ for all $S$. Thus, the settlement range under the proposed Rule $68,\left[S, U^{d}\right]$, will be at least as large as the one $\left[U^{p}, U^{d}\right]$ without the rule because $U^{d}-\underline{S} \geq U^{d}-U^{p}$. When $G^{p}\left(U^{p}\right)$ $G^{p}(0)>0$, we have to show that $U^{d}-\underline{S}>U^{d}-U^{p}$. Suppose to the contrary that $\underline{S}=U^{p}$. Then, we have $\underline{S} \equiv U^{p}-z^{p}(S)=U^{p}-z^{p}\left(U^{p}\right)<U^{p}$, which is a contradiction. The last inequality is obtained from $z^{p}\left(U^{p}\right)=\left(G^{p}\left(U^{p}\right)-G^{p}(0)\right)\left(C^{p}+C^{d}\right)>0$. When $G^{p}\left(U^{p}\right)$ $G^{p}(0)>0$, thus, we must have $\underline{S}<U^{p}$. This proves that if $G^{p}\left(U^{p}\right)-G^{p}(0)>0, U^{d}-\underline{S}>$ $U^{d}-U^{p}$

(ii) When $U^{d}<U^{p}$, the settlement range does not exist in the absence of Rule 68. It suffices to show that $\underline{S}<U^{d}$. Suppose to the contrary that $\underline{S} \geq U^{d}$. From the definition of $\underline{S}$, we have $\underline{S} \equiv U^{p}-z^{p}(S) \geq U^{d}$. Thus, we have (a) $U^{p}-U^{d} \geq z^{p}(S) \geq$ $z^{p}\left(U^{d}\right)$ since $z^{p}(S)$ is weakly increasing. From the definition of $z^{p}(S)$, we also have (b) $z^{p}\left(U^{d}\right) \equiv\left(G^{p}\left(U^{d}\right)-G^{p}(0)\right)\left(C^{p}+C^{d}\right)>U^{p}-U^{d}$, in which the last inequality is obtained from the condition in the proposition. Putting (a) and (b) together leads to $U^{p}-U^{d} \geq$ $z^{p}\left(U^{d}\right)>U^{p}-U^{d}$, which is a contradiction. Therefore, it must be that $\underline{S}<U^{d}$. Q.E.D. 


\section{FOOTNOTES}

* Assistant Professor of Economics, University of Western Ontario.

1 For the text of Rule 68, see infra note 23.

2 See Committee on Rules of Practice and Procedure of the Judicial Conference of the United States, Preliminary Draft of Proposed Amendments to the Federal Rules of Civil Procedure, 102 F.R.D. 407, 433 (1984). See also Joe Michels, Settlement Offers: The Role Rule 68 Can Play, 56 (3) Texas bar J. 224 (1993).

3 Important early works are George L. Priest, Regulating the Content and Volume of Litigation: An Economic Analysis, 1 Sup. Ct. Econ. Rev. 163 (1982), and Geoffrey P. Miller, An Economic Analysis of Rule 68, 15 J. Legal Stud. 93 (1986). Two recent works examining Rule 68 are David A. Anderson, Improving Settlement Devices: Rule 68 and Beyond, 23 J. Legal Stud. 225 (1994), and Kathryn E. Spier, Pretrial Bargaining and the Design of Fee-shifting Rules, 25 Rand J. Econ. 197 (1994).

4 The standard model of litigation has been developed by William M. Landes, An Economic Analysis of the Courts, 14 J. Law \& Econ. 61 (1971), Richard A. Posner, An Economic Approach to Legal Procedure and Judicial Administration, 2 J. Legal Stud. 399 (1973), John Gould, The Economics of Legal Conflicts, 2 J. Legal Stud. 279 (1973), and Steven Shavell, Suit, Settlement and Trial: A Theoretical Analysis under Alternative Methods for Allocation of Legal Costs, 11 J. Legal Stud. 55 (1982). For a general survey of the economic literature on litigation, see Robert D. Cooter and Daniel L. Rubinfield, Economic Analysis of Legal Disputes and Their Resolution, 27 J. Econ. Literature 1067 (1989). For a recent review of literature on the settlement of litigation, see Geoffrey P. Miller, Settlement of Litigation: A Critical Retrospective, mimeo, (1994).

5 See Posner, Economic Analysis of Law, 1992 (4th ed.), at 541. 
6 The numbers in this example are drawn from an example which is fully discussed at the end of Section I.

7 All of Miller's findings are shown to be consistent with this new definition.

8 For empirical works on Rule 68, see Thomas D. Rowe, Jr. with Neil Vidmar, Empirical Research on Offers of Settlement: A Preliminary Report, 51 L. \& Contemp. Probs. 13 (1988), and David A. Anderson and Thomas D. Rowe, Jr., Empirical Evidence on Settlement Devices: Does Rule 68 Encourage Settlement?, mimeo (1994).

9 For a related result, see Spier, supra note 3, which shows that when litigants have asymmetric information about the probability of prevailing, Rule 68 decreases the settlement rate.

10 This conclusion depends on the plaintiff's attitude toward risks.

11 See Miller, supra note 3.

12 See $i d$. at 107 (increasing parties' risk aversion will increase the litigation differential).

13 Although Federal Rule 54(d) gives district courts some discretion not to tax costs, the possibility is ignored in the main text.

14 The present model adopts a simplifying assumption that all litigation expenses other than attomey's fees are included in costs. The major distinction between fees and costs is that costs are potentially transferable under current Rule 68, whereas fees are not.

15 In the present model, parties' gain or loss is examined at the outset of the lawsuit, when neither party has incurred legal fees or costs. The model can be extended to consider gain or loss at some point in time after the filing of the complaint by following the approach taken in Miller, supra note 3.

16 See Miller, supra note 3, at 99. 
17 Examples are Landes, supra note 4, at 66 (a necessary condition for a settlement is that both the defendant and prosecutor simultaneously gain from a settlement compared to their expected trial outcomes); Shavell, supra note 4 , at 56-57 (plaintiff and defendant will reach a settlement if and only if there exists some settlement amount that both parties would prefer to going to trial); Anderson, supra note 3, at 228 (the settlement range consists of the set of Pareto-optimal settlement values between the two parties' threat points).

18 If $U^{p}>U^{d}$, it is said that settlement range does not exist because $\left[U^{p}, U^{d}\right]$ is an empty set.

19 See Posner, supra note 4, at 417 (the necessary condition for settlement is that the plaintiff's minimum offer be smaller than the defendant's maximum offer).

20 Figure 1 is adopted from Miller, supra note 3, at 101.

21 See $i d$. at 99 (settlement range refers to the range of settlement offers that it would be rational for the defendant to make and the plaintiff to accept). This definition implicitly assumes that the defendant is the only party who is allowed to make an offer. This will be true under the current version of Rule 68. A proposed amendment that has not been adopted allows both parties to make an offer of settlement.

22 Miller himself has used these two versions of settlement range interchangeably. See $i d$. at 104-105 (the settlement range under Rule 68 is the set of offers that are greater than or equal to the plaintiff's gain from trial at that offer and less than or equal to the defendant's loss from trial at that offer), and also at 105 (the highest amount it would be rational for the defendant to offer in settlement is the defendant's loss from trial since, with any higher figure, the defendant would rather go to trial than settle). 


\section{Rule 68 provides:}

At any time more than 10 days before trial begins, a party defending against a claim may serve upon the adverse party an offer to allow judgment to be taken against the defending party for the money or property or to the effect specified in the offer, with costs then accrued. If within 10 days after the service of the offer the adverse party serves written notice that the offer is accepted, either party may then file the offer and notice of acceptance together with proof of service thereof and thereupon the clerk shall enter judgment. An Offer not accepted shall be deemed withdrawn and evidence thereof is not admissible except in a proceeding to determine costs. If the judgment finally obtained by the offeree is not more favorable than the offer, the offeree must pay the costs incurred after the making of the offer. The fact that an offer is made but not accepted does not preclude a subsequent offer. When the liability of one party to another has been determined by verdict or order or judgment, but the amount or extent of the liability remains to be determined by further proceedings, the party adjudged liable may make an offer of judgment, which shall have the same effect as an offer made before trial if it is served within reasonable time not less than 10 days prior to the commencement of hearings to determine the amount or extent of liability. F.R.C.P. 68.

24 This post-offer settlement range has been confused with the settlement range that indicates the possibility of settlement of litigation. See the quotation by Miller, supra note 22. Other authors focus only on post-offer settlement ranges, see Anderson, supra note 3.

25 This has already been pointed out in Miller, supra note 3, at 103 . See also Anderson, supra note 3, at 234.

26 There may be a technical problem in defining these critical values because $G(S)$ can be discontinuous in some range of offers. In that case, it is defined by using a continuous extension (or approximation) of the distribution. 
27 Formally, $\bar{S} \equiv U^{d}(\bar{S})>U^{p} \geq U^{p}(S) \equiv \underline{S}$.

28 If the defendant makes zero offer or equivalently if the defendant does not make any offer, then the plaintiff's expected gain from trial will remain the same regardless of the presence of Rule 68 (formally, $U^{P}(S)=U^{p}$ when $S=0$ ). For large offers that are greater than or equal to $K$, plaintiff's expected gain from trial will be at its minimum (formally, $U^{P}(S)=\bar{x}-F^{p}-\left(C^{p}+C^{d}\right.$ ) for all $S \geq K$ ).

29 The conditions under which settlement range strictly expands are studied in Section III (Proposition 4).

30 In particular, the range of feasible settlements is smaller with the rule than without it, because $\bar{S}-\underline{S}=U^{d}-U^{p}-[z(\bar{S})-z(S)]<U^{d}-U^{p}$. The last inequality is obtained because $z(S)$ is increasing and $\bar{S}>\underline{S}$.

31 Miller, supra note 3, at 105.

32 For a discussion on the source of mutual optimism, see George Lowenstein, Samual Isacharoff, Colin Camerer and Linda Babcock, Self-Serving Assessments of Fairness and Pretrial Bargaining, 22 J. Legal Stud. 135 (1993).

33 This has also been observed in id. at 107-108.

34 See Priest, supra note 3, and Miller, supra note 3.

35 Miller also shows that when parties' beliefs are different, settlement could become possible as a result of Rule 68 (with the smaller settlement range $[\underline{S}, \bar{S}]$ ). See, Miller, supra note 3, at 108.

36 This example is adapted from the one in $i d$. at 97.

37 In Figure 4 and Figure 5 in which $\bar{S}<\underline{S}$, the offer $\underline{S}$ itself is equilibriumdominated by an offer, say $S^{1}$, that is slightly smaller than $\underline{S}$, but still greater than $\bar{S}$. The plaintiff's optimal response to $S^{1}$ is to reject because $U^{P}\left(S^{1}\right) \geq U^{P}(S) \equiv \underline{S}>S^{1}$. The defendant's expected loss with the offer $S^{1}$ when the plaintiff optimally responds is, thus, $U^{d}\left(S^{1}\right)$. From $\bar{S}<S^{1}$, we have $U^{d}\left(S^{1}\right) \leq U^{d}(\bar{S}) \equiv \bar{S}<\underline{S}$. This proves 
that $\underline{S}$ is equilibrium-dominated by $S^{1}$ because defendant's equilibrium expected loss with the offer $\underline{S}$ is $\underline{S}$.

38 Although settlement of litigation seems to be a social benefit, some arguments have also been made against settlement. See Miller, supra note 4, at 15-22.

39 Absent risk aversion, none of the existing or proposed offer rules is able to remedy a nonexistent settlement range, Anderson, supra note 3, at 228-229. In a model with asymmetric information, Rule 68 is shown to be helpful in alleviating the information problem. In particular, Kathryn E. Spier considers a model with one-sided incomplete information, and shows that Rule 68 will tend to increase the likelihood of settlement by relaxing the incentive compatibility constraints, see Spier, supra note 3.

40 This separation argument is similar in spirit to the decoupling liability system in which the award to the plaintiff differs from the payment by the defendant. See Polinsky and Che, Decoupling Liability: Optimal Incentives for Care and Litigation, 22 Rand J. Econ. 562 (1991).

41 Although the arguments in this subsection and the nest subsection are made for the proposed revision of Rule 68, those also are relevant to the current Rule 68 .

42 Posner has provided such an example, supra note 5, at 574-576 (in some cases, the defendant will find impossible to make a Rule 68 offer that will beat the judgment at trial if the case goes to trial and the plaintiff wins).

43 See, Notes, The proposed Amendment to Federal Rule of Civil Procedure 68: Toughening the Sanctions, 70 Iowa L. Rev. 237 (1984) at 256 (it [Rule 68] could discourage certain litigants and types of litigation. Poor and middle class litigants may be deterred from pursuing legitimate claims).

44 See, Priest, supra note 3. 